\title{
Bartonella rattaustraliani sp. nov., Bartonella queenslandensis sp. nov. and Bartonella coopersplainsensis sp. nov., identified in Australian rats
}

\author{
Vijay A. K. B. Gundi, ${ }^{1}$ Carmel Taylor $^{2}{ }^{\text {Didier Raoult }}{ }^{1}$ \\ and Bernard La Scola ${ }^{1}$ \\ ${ }^{1}$ URMITE, CNRS IRD UMR 6236, Faculté de Médecine, Université de la Méditerranée, 27 \\ Boulevard Jean Moulin, 13385 Marseille Cedex 05, France \\ ${ }^{2}$ Public Health Virology, Queensland Health Forensic and Scientific Services, Coopers Plains, QLD \\ 4108, Australia
}

Correspondence

Bernard La Scola

bernard.lascola@medecine.univmrs.fr

\begin{abstract}
A total of 11 Bartonella isolates were recovered from the blood of Melomys, Uromys and Rattus species in Australia and were characterized using phenotypic and genotypic methods.

Comparison of $16 \mathrm{~S}$ rRNA gene, fts $Z$, gltA and 16S-23S rRNA internal transcribed spacer region sequences from the isolates indicated that they formed three sequence similarity groups that were distinct from one another and from the currently recognized Bartonella species. Phylogenetic analysis based on alignment of concatenated sequences inferred distinct evolutionary lineages for each of the three groups within the genus Bartonella. On the basis of these data, we propose the isolates be accommodated in three novel Bartonella species, namely Bartonella rattaustraliani sp. nov. (type strain AUST/NH4 ${ }^{\top}=$ CIP $109051^{\top}=$ CCUG $52161^{\top}=$ CSUR B609 $^{\top}$ ), Bartonella queenslandensis sp. nov. (type strain AUST/NH12 $2^{\top}=\mathrm{CIP} 109057^{\top}=\mathrm{CCUG}^{2} 2167^{\top}=\mathrm{CSUR}$ $\mathrm{B} 617^{\top}$ ) and Bartonella coopersplainsensis sp. nov. (type strain AUST/NH20 ${ }^{\top}=\mathrm{CIP} 109064^{\top}$ $=$ CCUG $52174^{\top}=$ CSUR B619 ${ }^{\top}$ ).
\end{abstract}

Bacteria of the genus Bartonella (a member of the Alphaproteobacteria) are fastidious, Gram-negative and aerobic bacilli. The genus currently consists of 19 species, including three subspecies of Bartonella vinsonii, and some subtypes of Bartonella quintana and Bartonella henselae. Of these, among species with validly published names, Bartonella elizabethae, B. bacilliformis, B. quintana, $B$. koehlerae, B. henselae, B. grahamii, B. alastica, B. clarridgeiae and the three subspecies of $B$. vinsonii have been recognized as potential human pathogens, in addition to currently unnamed isolates (Breitschwerdt \& Kordick, 2000; Chomel et al., 2006a; Minnick \& Anderson, 2006; Eremeeva et al., 2007; Kosoy et al., 2008). Numerous reports have been made of the worldwide occurrence of Bartonella organisms in ruminants, rodents and pets (Chomel et al., 2006b). There has been increased interest

Abbreviation: ITS, 16S-23S rRNA internal transcribed spacer.

The GenBank/EMBL/DDBJ accession numbers for the 16S rRNA gene, ITS, fts $Z, r p o B$ and gltA sequences determined in this study are EU111749-EU111803, as detailed in Table 1.

Neighbour-joining dendrograms based on individual analysis of ITS, ftsZ, rpo $B$ and $g l t A$ sequences and a table of accession numbers of reference sequences are available as supplementary material with the online version of this paper. in the isolation and description of novel species of the genus (Castle et al., 2004). Recent studies have shown that bartonellae were widely distributed among rodents in southern China (Ying et al., 2002), Thailand (Castle et al., 2004) and Bangladesh (Bai et al., 2007). To our knowledge, no isolates have previously been recovered from rats in Australia. The purpose of the present study was to characterize a group of Bartonella strains isolated from rodents in Australia.

Animal blood was collected during two separate mammal surveys carried out in Queensland, Australia, in 1999. The first was performed by the Australian Army and involved collection of tissues and blood from mammals trapped in central Queensland. The second survey was carried out by Queensland Health and involved trapping small mammals in north Queensland. Blood was collected from each animal and transferred to the laboratory where, upon arrival, the samples were placed at $-80{ }^{\circ} \mathrm{C}$ for long-term storage.

Each vial of blood was thawed for isolation of Bartonella strains, which was carried out as described previously (Heller et al., 1998). Putative bartonella colonies were subcultured by streaking onto heart infusion agar plates 
supplemented with $5 \%$ defibrinated sheep blood (Microdiagnostics). Cultures were then stored frozen in brain heart infusion broth containing glycerol. Cultures were retrieved from frozen storage and subjected to DNA extraction using Qiagen blood kits. PCR was then performed as described previously (La Scola et al., 2002). Cultures that were positive by PCR were shipped frozen on dry ice to the Unité des Rickettsies of the Faculté de Médecine at Marseille, France, for further studies.

Electron microscopy was performed for size determination and flagella study. Bacterial isolates were grown in solid and liquid media and submitted to electron microscopy as described previously (Maillard et al., 2004). Briefly, the bacteria were suspended in PBS $(0.145 \mathrm{M} \mathrm{NaCl}, 0.15 \mathrm{M}$ sodium phosphate), spread on a water surface and adsorbed to Formvar-coated nickel grids, stained with $1 \%(\mathrm{w} / \mathrm{v})$ uranyl acetate and air-dried. Samples were examined with a Philips transmission electron microscope.

Molecular characterization was performed by sequence analysis of the 16S rRNA gene, the 16S-23S rRNA internal transcribed spacer (ITS) and the $f t s Z, r p o B$ and gltA genes according to methods described previously (Birtles et al., 1995; Birtles \& Raoult, 1996; Renesto et al., 2001; Zeaiter et al., 2002; Houpikian \& Raoult, 2001). For $g l t A$, a 964 bp fragment encompassing the $326 \mathrm{bp}$ hypervariable region was sequenced. The hypervariable region was used for similarity comparisons for consistency with our earlier study (La Scola et al., 2003), whereas the large fragment was used for phylogeny as it was expected to be more informative in phylogenetic tree reconstruction.

Eleven Bartonella isolates from Australian rats were studied: two from Rattus tunneyi, one from Rattus fuscipes, one from Uromys caudimaculatus, two from Rattus conatus, three from Rattus leucopus and two from Melomys sp. Based on phenotypic characteristics (small, Gram-negative bacilli better observed by Gimenez staining, slow growth on blood agar but not on nutrient agar), the organisms were initially suspected to be Bartonella strains.

The ranges of sequence similarity of the isolates to the closest members of Bartonella for the 16S rRNA gene, ITS, fts $Z, r p o B$ and gltA sequence were respectively 98.9-99.7, 80.5-94.2, 89.1-98.3, 89.5-95.9 and 89.0-95.4\% (Table 1). The 11 isolates were scattered into two different clusters in the neighbour-joining phylogenetic tree constructed with concatenated 16S rRNA gene, ITS, ftsZ, rpoB and gltA sequences (cluster 1: AUST/NH4 $4^{\mathrm{T}}$, AUST/NH9, AUST/ NH10, AUST/NH14 and AUST/NH18; cluster 2a: AUST/ NH5, AUST/NH8, AUST/NH11, AUST/NH12 ${ }^{\mathrm{T}}$ and AUST/NH15; cluster 2b: AUST/NH20 ${ }^{\mathrm{T}}$ ) (Fig. 1; accession numbers for individual reference sequences are detailed in Supplementary Table S1, available in IJSEM Online. This suggested that these isolates could represent three novel species. In the concatenated phylogenetic tree, cluster 1 isolates shared a branch with Bartonella tribocorum, $B$. grahamii and $B$. elizabethae. The branching pattern and distribution of the new isolates in trees constructed with individual genes were the same as in the concatenated tree (Supplementary Fig. S1). The branching of members of cluster 2 is more difficult to appreciate, as it is not supported by high bootstrap values in the concatenated tree or in the individual trees. We proposed to classify these isolates in three novel species, Bartonella rattaustraliani sp. nov. (isolates AUST/NH4 ${ }^{\mathrm{T}}, \mathrm{AUST} / \mathrm{NH} 9, \mathrm{AUST} / \mathrm{NH} 10$, AUST/NH14 and AUST/NH18), Bartonella queenslandensis sp. nov. (isolates AUST/NH5, AUST/NH8, AUST/NH11, AUST/NH12 $2^{\mathrm{T}}$ and AUST/NH15) and Bartonella coopersplainsensis sp. nov. (isolate AUST/NH20 ${ }^{\mathrm{T}}$ ). The ranges of similarity of these novel species to their closest relatives and levels of intraspecies similarity are summarized in Table 2 . The latter isolate AUST/ $\mathrm{NH} 20^{\mathrm{T}}$ was closely related to but distinct from isolates of cluster $2 \mathrm{a}$, as its closest relatives were the novel strain AUST/NH4 ${ }^{\mathrm{T}}$ (B. rattaustraliani $\mathrm{sp}$. nov.) for the glt $A, r p o B$ and $f t s Z$ sequences, with $92.3,93.8$ and $92.9 \%$ similarity, respectively, and $B$. grahamii $\mathrm{V}^{\mathrm{T}}$ for the 16S rRNA gene and ITS sequences, with 98.7 and $81.9 \%$ similarity, respectively.

The ad hoc committee for the re-evaluation of the species definition in bacteriology has previously proposed that descriptions of novel species could be based on housekeeping gene sequence analysis with a comparison of at least five genes, provided there is a sufficient degree of congruence between the technique used and DNA-DNA reassociation (Stackebrandt et al., 2002). For Bartonella species, it was added that there should be congruence of multilocus gene analysis with results of phylogenetic analysis based on gene sequence analysis that give high bootstrap values (Pitulle et al., 2002). In a study by La Scola et al. (2003), we compared similarities of several coding sequences between known species of Bartonella and identified that several genes such as ribC could not provide firm evidence that a new isolate of Bartonella represented a novel species. For this gene, in nearly all cases, similarity between species did not exceed $93 \%$; however, for two species, it was as high as $99.5 \%$, suggesting horizontal gene transfer (La Scola et al., 2003). Of the genes studied, only partial $r p o B$ and glt $A$ sequences, with respective interspecies similarities of 95.4 and $96 \%$, allowed clear discrimination of all species. From these data, we proposed that newly encountered Bartonella isolates should be considered to represent novel species if the hypervariable $327 \mathrm{bp}$ gltA fragment shares less than $96 \%$ sequence similarity and if a 825 bp rpoB fragment shares less than $95.4 \%$ sequence similarity with sequences of strains of species with validly published names (La Scola et al., 2003). In the present case, through analysis of $825 \mathrm{bp} r p o B$ sequences, five isolates, AUST/NH5, AUST/NH8, AUST/NH11, AUST/NH12 ${ }^{\mathrm{T}}$ and AUST/NH15, showed $95.5-96.0 \%$ similarity with members of the closest species. These values are above the proposed cut-off value of $95.4 \%$. However, these five isolates show 92.3-95.4\% similarity to strains of known Bartonella species for the $327 \mathrm{bp}$ gltA fragment, for which the determined cut-off value is $96.0 \%$ (La Scola et al., 2003). Thus, in the present study, as the $r p o B$ gene sequence 
Table 1. Sequence similarity to their closest relatives for the Bartonella isolates from the present study

Details of the sequences of the closest relatives are given in Supplementary Table S1.

\begin{tabular}{|c|c|c|c|}
\hline Strain & Sequence & GenBank accession no. & Closest relative(s) (similarity, \%) \\
\hline \multicolumn{4}{|c|}{ Bartonella rattaustraliani sp. nov. } \\
\hline \multirow[t]{5}{*}{ AUST/NH $4^{\mathrm{T}}$} & 16S rRNA gene & EU111749 & B. vinsonii subsp. vinsonii (99.4) \\
\hline & ITS & EU111760 & B. grahamii $(80.5)$ \\
\hline & fts $Z$ & EU111771 & B. vinsonii subsp. berkhoffii (95.9) \\
\hline & $r p o B$ & EU111782 & B. vinsonii subsp. berkhoffii/B. vinsonii subsp. vinsonii (90.3) \\
\hline & gltA & EU111793 & B. vinsonii subsp. arupensis (89.9) \\
\hline \multirow[t]{5}{*}{ AUST/NH9 } & 16S rRNA gene & EU111750 & B. doshiae (99.3) \\
\hline & ITS & EU111761 & B. grahamii (84.1) \\
\hline & fts $Z$ & EU111772 & B. vinsonii subsp. vinsonii (96.5) \\
\hline & $r p o B$ & EU111783 & B. vinsonii subsp. berkhoffii (89.5) \\
\hline & gltA & EU111794 & B. grahamii $(90.2)$ \\
\hline \multirow[t]{5}{*}{ AUST/NH10 } & 16S rRNA gene & EU111751 & B. vinsonii subsp. berkhoffii (99.3) \\
\hline & ITS & EU111762 & B. grahamii $(81.3)$ \\
\hline & fts $Z$ & EU111773 & B. vinsonii subsp. vinsonii (94.8) \\
\hline & $r p o B$ & EU111784 & B. vinsonii subsp. arupensis (89.8) \\
\hline & gltA & EU111795 & B. vinsonii subsp. arupensis (89.9) \\
\hline \multirow[t]{5}{*}{ AUST/NH14 } & 16S rRNA gene & EU111752 & B. vinsonii subsp. berkhoffii (99.3) \\
\hline & ITS & EU111763 & B. grahamii (81.1) \\
\hline & $f t s Z$ & EU111774 & B. vinsonii subsp. vinsonii (95.4) \\
\hline & $r p o B$ & EU111785 & B. vinsonii subsp. arupensis (90.3) \\
\hline & gltA & EU111796 & B. vinsonii subsp. arupensis (90.5) \\
\hline \multirow[t]{5}{*}{ AUST/NH18 } & 16S rRNA gene & EU111753 & B. vinsonii subsp. vinsonii (99.3) \\
\hline & ITS & EU111764 & B. grahamii $(84.1)$ \\
\hline & fts $Z$ & EU111775 & B. vinsonii subsp. vinsonii (96.4) \\
\hline & $r p o B$ & EU111786 & B. vinsonii subsp. berkhoffii (89.7) \\
\hline & gltA & EU111797 & B. grahamii $(90.2)$ \\
\hline \multicolumn{4}{|c|}{ Bartonella queenslandensis sp. nov. } \\
\hline \multirow[t]{5}{*}{ AUST/NH5 } & 16S rRNA gene & EU111755 & B. grahamii (99.6) \\
\hline & ITS & EU111766 & B. tribocorum (93.5) \\
\hline & fts $Z$ & EU111777 & B. elizabethae (98.0) \\
\hline & $r p o B$ & EU111788 & B. tribocorum (95.9) \\
\hline & gltA & EU111799 & B. grahamii (95.1) \\
\hline \multirow[t]{5}{*}{ AUST/NH8 } & 16S rRNA gene & EU111756 & B. vinsonii subsp. vinsonii (99.7) \\
\hline & ITS & EU111767 & B. tribocorum $(94.0)$ \\
\hline & $f t s Z$ & EU111778 & B. elizabethae (97.9) \\
\hline & $r p o B$ & EU111789 & B. tribocorum (95.5) \\
\hline & gltA & EU111800 & B. grahamii (94.5) \\
\hline \multirow[t]{5}{*}{ AUST/NH11 } & $16 \mathrm{~S}$ rRNA gene & EU111757 & B. vinsonii subsp. vinsonii (99.7) \\
\hline & ITS & EU111768 & B. tribocorum (93.6) \\
\hline & $f t s Z$ & EU111779 & B. elizabethae (98.3) \\
\hline & $r p o B$ & EU111790 & B. tribocorum (95.8) \\
\hline & gltA & EU111801 & B. grahamii (95.1) \\
\hline \multirow[t]{5}{*}{ AUST/NH $12^{\mathrm{T}}$} & 16S rRNA gene & EU111754 & B. vinsonii subsp. vinsonii (99.6) \\
\hline & ITS & EU111765 & B. tribocorum (93.7) \\
\hline & $f t s Z$ & EU111776 & B. vinsonii subsp. berkhoffii (95.9) \\
\hline & $r p o B$ & EU111787 & B. tribocorum (95.6) \\
\hline & gltA & EU111798 & B. grahamii (94.8) \\
\hline \multirow[t]{5}{*}{ AUST/NH15 } & 16S rRNA gene & EU111758 & B. vinsonii subsp. vinsonii (99.7) \\
\hline & ITS & EU111769 & B. tribocorum (94.2) \\
\hline & $f t s Z$ & EU111780 & B. elizabethae (98.0) \\
\hline & $r p o B$ & EU111791 & B. tribocorum (96.0) \\
\hline & gltA & EU111802 & B. grahamii (95.4) \\
\hline \multicolumn{4}{|c|}{ Bartonella coopersplainsensis sp. nov. } \\
\hline \multirow[t]{2}{*}{ AUST/NH $20^{\mathrm{T}}$} & 16S rRNA gene & EU111759 & B. grahamii (98.7) \\
\hline & ITS & EU111770 & B. grahamii (81.9) \\
\hline
\end{tabular}


Table 1. cont.

\begin{tabular}{|llll|}
\hline Strain & Sequence & GenBank accession no. & \multicolumn{1}{c|}{ Closest relative(s) (similarity, \%) } \\
\hline & $f t s Z$ & EU111781 & B. vinsonii subsp. vinsonii (89.1) (AUST/NH4 $\left.{ }^{\mathrm{T}}, 92.9\right)$ \\
& gltA & EU111792 & B. alsatica (91.9) (AUST/NH4 $\left.{ }^{\mathrm{T}}, 93.8\right)$ \\
& EU111803 & B. vinsonii subsp. arupensis (89.0) (AUST/NH4 $\left.4^{\mathrm{T}}, 92.3\right)$ \\
\hline
\end{tabular}

similarities exceeded the proposed cut-off, analysis of the sequences of more genes had to be performed. However, it should be noticed that gltA and $r p o B$ fragments still give the highest confidence for definition of novel species as, in all cases, the intraspecies similarity of sequences from $B$. rattaustraliani and $B$. coopersplainsensis strains is greater than the interspecies similarity.

In the concatenated phylogenetic tree, strains of the newly proposed species $B$. queenslandensis branched strictly with B. tribocorum, B. elizabethae and B. grahamii. B. rattaustraliani and $B$. coopersplainsensis branched consistently with Bartonella doshiae and B. taylorii (Fig. 1), but the relationships with other species are not well-defined.

In conclusion, for the first time, Bartonella species have been recovered from rats in Australia. The sequences of five genomic regions, gltA, rpoB, the $16 \mathrm{~S}$ rRNA gene, fts $Z$ and the ITS region, reveal similarity values in the range that allows the isolates to be afforded distinct species status. To fulfil the rules of the International Code of Nomenclature of Bacteria (Lapage et al., 1992), we provide the following descriptions of the novel species identified in this investigation.

\section{Description of Bartonella rattaustraliani sp. nov.}

Bartonella rattaustraliani (ratt.aus.tra.li.a' ni. N.L. n. Rattus zoological name of a genus of rat; N.L. adj. australianus Australian; N.L. gen. n. rattaustraliani of an Australian rat, from which the first strains were isolated).

All five known isolates assigned to the species exhibit all of the characteristics of the genus (Birtles et al., 1995). Good growth is observed on Columbia agar with $5 \%$ sheep blood in a $5 \% \mathrm{CO}_{2}$ atmosphere at $37{ }^{\circ} \mathrm{C}$, where colonies appear small, white, smooth and irregular (about $0.5 \mathrm{~mm}$ in diameter) after 7 days. Electron microscope examination reveals small bacilli without flagella, approx. 1-2 $\mu \mathrm{m}$ long by $0.5 \mu \mathrm{m}$ wide. Gram-negative and Gimenez-positive. All known strains are susceptible to antibiotics such as aminoglycosides, macrolides, doxycycline and rifampicin, but are resistant to vancomycin. Moreover, imipenem is more effective against all known strains except AUST/

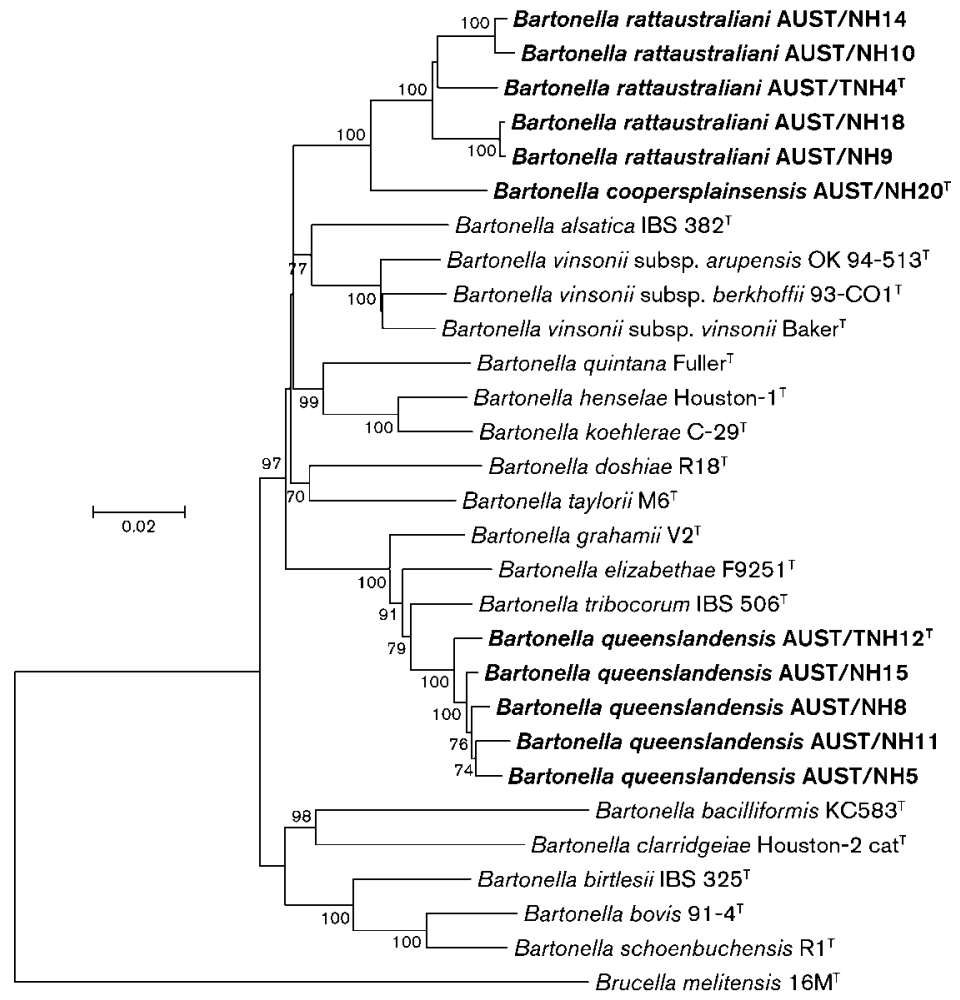

Fig. 1. Dendrogram representing the phylogenetic relationships between Bartonella species, derived from concatenated sequences of the 16S rRNA gene, the ITS region and the $r p o B$, fts $Z$ and gltA sequences. MEGA4 software (http://www.megasoftware.net) was used to infer the tree by using the neighbourjoining method with Kimura's two-parameter model. Support for each branch, as determined from 1000 bootstrap samples, is indicated by percentages at nodes. Accession numbers for individual refererence sequences are detailed in Supplementary Table S1. Concatenated sequences from Brucella melitensis $16 \mathrm{M}^{\top}$ were used as an outgroup. Bar, 0.02 substitutions per nucleotide position. 
Table 2. Ranges of similarity (\%) with their closest relatives and intraspecies similarity (\%) of the three novel species

'Intra' refers to intraspecies sequence similarity; B. coopersplainsensis sp. nov. accommodates only a single strain.

\begin{tabular}{|c|c|c|c|c|c|c|c|c|}
\hline \multirow[t]{2}{*}{ Species } & \multicolumn{2}{|c|}{ ITS } & \multicolumn{2}{|c|}{$f t s Z$} & \multicolumn{2}{|c|}{ rpoB } & \multicolumn{2}{|c|}{ gltA } \\
\hline & Range & Intra & Range & Intra & Range & Intra & Range & Intra \\
\hline B. rattaustraliani & $81.1-84.1$ & $81-99.6$ & $94-96.5$ & $95.8-99.6$ & $89.5-90.3$ & $93.2-99.3$ & $89.9-90.5$ & $94.8-100$ \\
\hline B. queenslandensis & $93.5-94.2$ & $95.1-97.9$ & $95.9-98.3$ & $98.5-99.7$ & $95.5-96$ & $97.9-99.4$ & $94.5-95.4$ & $96.3-100$ \\
\hline B. coopersplainsensis & 81.9 & NA & 92.9 & NA & 93.8 & NA & 92.3 & NA \\
\hline
\end{tabular}

$\mathrm{NH} 4^{\mathrm{T}}$. The type strain of the species is non-motile. It is differentiated genetically from other Bartonella species on the basis of sequences of the $16 \mathrm{~S}$ rRNA, fts $Z$, glt $A$ and $r p o B$ genes and the ITS region.

The type strain is AUST/NH4 ${ }^{\mathrm{T}}\left(=\mathrm{CIP} 109051^{\mathrm{T}}=\mathrm{CCUG}\right.$ $52161^{\mathrm{T}}=$ CSUR B $609^{\mathrm{T}}$ ), isolated from blood of a wild rat of the species Rattus tunneyi. Other isolates belonging to the same species, isolated from the blood of rats, are AUST/ NH9 (=CIP $109055=$ CCUG $52164=$ =CSUR B610) from Uromys caudimaculatus, AUST/NH10 (=CIP 109054 =CCUG $52165=$ CSUR B611) from Rattus leucopus, AUST/NH14 (=CIP $109059=$ CCUG $52169=\mathrm{CSUR}$ B612) from Rattus conatus and AUST/NH18 (=CIP 109063 =CCUG 52173 =CSUR B613) from Melomys sp.

\section{Description of Bartonella queenslandensis sp. nov.}

Bartonella queenslandensis (queens.lan.den'sis. N.L. fem. adj. queenslandensis referring to Queensland, the Australian state where the rats were trapped from which the first strains were isolated).

All six known isolates assigned to the species exhibit all of the characteristics of the genus (Birtles et al., 1995). Good growth is observed on Columbia agar with $5 \%$ sheep blood in a $5 \% \mathrm{CO}_{2}$ atmosphere at $37{ }^{\circ} \mathrm{C}$, where colonies appear small, white, smooth and irregular (about $0.5 \mathrm{~mm}$ in diameter) after 7 days. Electron microscope examination reveals small bacilli without flagella, approximately $1-2 \mu \mathrm{m}$ long by $0.5 \mu \mathrm{m}$ wide. Gram-negative, Gimenez-positive. All known strains show susceptibility to aminoglycosides, macrolides, doxycycline and rifampicin, but are resistant to vancomycin. Furthermore, imipenem is more effective against all strains. The type strain of the species is nonmotile. It is differentiated genetically from other Bartonella species on the basis of sequences of the 16S rRNA, fts $Z$, gltA and $r p o B$ genes and the ITS region.

The type strain is AUST/NH12 ${ }^{\mathrm{T}}\left(=\mathrm{CIP} 109057^{\mathrm{T}}=\mathrm{CCUG}\right.$ $52167^{\mathrm{T}}=$ CSUR B $617^{\mathrm{T}}$ ), isolated from blood of a wild rat belonging to the genus Melomys. Other isolates belonging to the species, isolated from the blood of rats, are AUST/ NH5 (=CIP 109052 =CCUG 52162 =CSUR B614) from Rattus tunneyi, AUST/NH8 (=CIP 109053 =CCUG 52163 =CSUR B615) from Rattus fuscipes, AUST/NH11 (=CIP 109056 =CCUG 52166 =CSUR B616) from Rattus conatus and AUST/NH15 (=CIP $109060=$ CCUG $52170=$ CSUR B618) from Rattus leucopus.

\section{Description of Bartonella coopersplainsensis sp. nov.}

Bartonella coopersplainsensis (coo.pers.plain.sen'sis. N.L. fem. adj. coopersplainsensis pertaining to Coopers Plains, Queensland, the name of the area where the rat was trapped from which the type strain was isolated).

The single known isolate assigned to this species exhibits all of the characteristics of the genus (Birtles et al., 1995). Good growth is observed on Columbia agar with $5 \%$ sheep blood in a $5 \% \mathrm{CO}_{2}$ atmosphere at $37{ }^{\circ} \mathrm{C}$, where colonies appear small, white, smooth and irregular (about $0.5 \mathrm{~mm}$ in diameter) after 20 days. Electron microscope examination reveals small bacilli without flagella, approximately 1$2 \mu \mathrm{m}$ long by $0.5 \mu \mathrm{m}$ wide. Gram-negative and Gimenezpositive, and non-motile. Susceptible to aminoglycosides, macrolides, doxycycline and rifampicin; resistant to vancomycin, and imipenem is more effective against the type strain. Differentiated genetically from other Bartonella species on the basis of sequences of the $16 \mathrm{~S}$ rRNA, fts $Z$, gltA and $r p o B$ genes and the ITS region.

The type strain is AUST/NH20 ${ }^{\mathrm{T}}$ (=CIP $109064^{\mathrm{T}}=\mathrm{CCUG}$ $52174^{\mathrm{T}}=$ CSUR B619 ${ }^{\mathrm{T}}$ ), isolated from blood of a wild rat of the species Rattus leucopus.

\section{Acknowledgements}

The authors wish to thank the following Queensland Health staff who were involved in animal trapping: Greg Smith, Ina Smith, Lee Smythe, Michael Dohnt and Meegan Symonds.

\section{References}

Bai, Y., Montgomery, S. P., Sheff, K. W., Chowdhury, M. A., Breiman, R. F., Kabeya, H. \& Kosoy, M. Y. (2007). Bartonella strains in small mammals from Dhaka, Bangladesh, related to Bartonella in America and Europe. Am J Trop Med Hyg 77, 567-570.

Birtles, R. J. \& Raoult, D. (1996). Comparison of partial citrate synthase gene ( gltA) sequences for phylogenetic analysis of Bartonella species. Int J Syst Bacteriol 46, 891-897.

Birtles, R. J., Harrison, T. G., Saunders, N. A. \& Molyneux, D. H. (1995). Proposals to unify the genera Grahamella and Bartonella, with descriptions of Bartonella talpae comb. nov., Bartonella peromysci 
comb. nov., and three new species, Bartonella grahamii sp. nov., Bartonella taylorii sp. nov., and Bartonella doshiae sp. nov. Int J Syst Bacteriol 45, 1-8.

Breitschwerdt, E. B. \& Kordick, D. L. (2000). Bartonella infection in animals: carriership, reservoir potential, pathogenicity, and zoonotic potential for human infection. Clin Microbiol Rev 13, 428-438.

Castle, K. T., Kosoy, M., Lerdthusnee, K., Phelan, L., Bai, Y., Gage, K. L., Leepitakrat, W., Monkanna, T., Khlaimanee, N. \& other authors (2004). Prevalence and diversity of Bartonella in rodents of northern Thailand: a comparison with Bartonella in rodents from southern China. Am J Trop Med Hyg 70, 429-433.

Chomel, B. B., Boulouis, H. J., Maruyama, S. \& Breitschwerdt, E. B. (2006a). Bartonella spp. in pets and effect on human health. Emerg Infect Dis 12, 389-394.

Chomel, B. B., Kasten, R. W., Henn, J. B. \& Molia, S. (2006b). Bartonella infection in domestic cats and wild felids. Ann N Y Acad Sci 1078, 410-415.

Eremeeva, M. E., Gerns, H. L., Lydy, S. L., Goo, J. S., Ryan, E. T., Mathew, S. S., Ferraro, M. J., Holden, J. M., Nicholson, W. L. \& other authors (2007). Bacteremia, fever, and splenomegaly caused by a newly recognized Bartonella species. N Engl J Med 356, 2381-2387.

Heller, R., Riegel, P., Hansmann, Y., Delacour, G., Bermond, D., Dehio, C., Lamarque, F., Monteil, H., Chomel, B. \& Piémont, Y. (1998). Bartonella tribocorum sp. nov., a new Bartonella species isolated from the blood of wild rats. Int J Syst Bacteriol 48, 1333-1339.

Houpikian, P. \& Raoult, D. (2001). 16S/23S rRNA intergenic spacer regions for phylogenetic analysis, identification, and subtyping of Bartonella species. J Clin Microbiol 39, 2768-2778.

Kosoy, M., Morway, C., Sheff, K. W., Bai, Y., Colborn, J., Chalcraft, L., Dowell, S. F., Peruski, L. F., Maloney, S. A. \& other authors (2008). Bartonella tamiae sp. nov., a newly recognized pathogen isolated from three human patients from Thailand. J Clin Microbiol 46, 772-775.

Lapage, S. P., Sneath, P. H. A., Lessel, E. F., Skerman, V. B. D., Seeliger, H. P. R. \& Clark, W. A. (editors) (1992). International Code of Nomenclature of Bacteria (1990 Revision). Bacteriological Code. Washington, DC: American Society for Microbiology.

La Scola, B., Davoust, B., Boni, M. \& Raoult, D. (2002). Lack of correlation between Bartonella DNA detection within fleas, serological results, and results of blood culture in a Bartonella-infected stray cat population. Clin Microbiol Infect 8, 345-351.

La Scola, B., Zeaiter, Z., Khamis, A. \& Raoult, D. (2003). Genesequence-based criteria for species definition in bacteriology: the Bartonella paradigm. Trends Microbiol 11, 318-321.

Maillard, R., Riegel, P., Barrat, F., Bouillin, C., Thibault, D., Gandoin, C., Halos, L., Demanche, C., Alliot, A. \& other authors (2004). Bartonella chomelii sp. nov., isolated from French domestic cattle (Bos taurus). Int J Syst Evol Microbiol 54, 215-220.

Minnick, M. F. \& Anderson, B. E. (2006). The genus Bartonella. In The Prokaryotes: a Handbook on the Biology of Bacteria, 3rd edn, vol. 5, pp. 467-492. Edited by M. Dworkin, S. Falkow, E. Rosenberg, K. H. Schleifer \& E. Stackebrandt. New York: Springer.

Pitulle, C., Strehse, C., Brown, J. W. \& Breitschwerdt, E. B. (2002). Investigation of the phylogenetic relationships within the genus Bartonella based on comparative sequence analysis of the $\operatorname{rnp} B$ gene, 16S rDNA and 23S rDNA. Int J Syst Evol Microbiol 52, 2075-2080.

Renesto, P., Gouvernet, J., Drancourt, M., Roux, V. \& Raoult, D. (2001). Use of $r p o B$ gene analysis for detection and identification of Bartonella species. J Clin Microbiol 39, 430-437.

Stackebrandt, E., Frederiksen, W., Garrity, G. M., Grimont, P. A. D., Kämpfer, P., Maiden, M. C. J., Nesme, X., Rosselló-Mora, R., Swings, J. \& other authors (2002). Report of the ad hoc committee for the reevaluation of the species definition in bacteriology. Int J Syst Evol Microbiol 52, 1043-1047.

Ying, B., Kosoy, M. Y., Maupin, G. O., Tsuchiya, K. R. \& Gage, K. L. (2002). Genetic and ecologic characteristics of Bartonella communities in rodents in southern China. Am J Trop Med Hyg 66, 622-627.

Zeaiter, Z., Liang, Z. \& Raoult, D. (2002). Genetic classification and differentiation of Bartonella species based on comparison of partial ftsZ gene sequences. J Clin Microbiol 40, 3641-3647. 